\title{
ZARZĄDZANIE PLYNNOŚCIĄ MAKROEKONOMICZNĄ PRZEZ EUROPEJSKI BANK CENTRALNY W KRYZYSIE FINANSOWYM
}

\begin{abstract}
Streszczenie
W artykule przedstawiono przyczyny kryzysu finansowego powstałego w 2008 roku, jego negatywne skutki dla Eurosystemu i nadzwyczajne działanie Europejskiego Banku Centralnego (EBC) w zarządzaniu płynnością finansowa. Straty banków komercyjnych, które zainwestowały w obligacje zabezpieczone aktywami pochodzacymi z sekurytyzacji kredytów hipotecznych wysokiego ryzyka w USA, spowodowały niedobór płynności finansowej i poważne zakłócenia na rynkach finansowych.

Europejski Bank Centralny, starając się zabezpieczyć rynki przed ryzykiem płynności, wprowadził dodatkowe rozwiązania w zarządzaniu płynnością, takie jak: dostarczenie bankom strefy euro nieograniczonych kwot płynności, obniżenie kosztów pośrednictwa banku centralnego bankom komercyjnym, dostarczenie płynności w walutach obcych (USD, CHF) poprzez umowy swapowe i repo z zagranicznymi bankami centralnymi, rozszerzenie listy aktywów akceptowanych jako zabezpieczenie operacji zasilających w pieniądz, wprowadzenie programów zakupu nadmiaru obligacji skarbowych od banków w celu przywrócenia równowagi na rynku tych papierów.
\end{abstract}

Słowa kluczowe: kryzys finansowy, płynność finansowa, operacje refinansujące

\section{MACROECONOMIC LIQUIDITY MANAGEMENT BY EUROPEAN CENTRAL BANK IN FINANCIAL CRISIS}

\section{Summary}

The paper presents the causes of the financial crisis of 2008, its negative implications for the Eurosystem, and the emergency action taken by the ECB to manage financial liquidity. The losses of commercial banks, which had invested in bonds secured by assets derived from the securitisation of subprime mortgages in the USA, resulted in a shortage of liquidity and a serious disturbance in the financial markets.

In an attempt to protect markets against the risk of liquidity, the ECB introduced additional liquidity management solutions: providing euro area banks with unlimited amounts of liquidity, reducing the cost of central bank intermediation for commercial banks, offering the liquidity in foreign currencies (USD,CHF) through swaps and repurchase of limited central banks, expanding the list of assets accepted as collateral in money supply operations, the introduction of excess purchase programmes of treasury bonds from banks in order to roll over the balance of the securities markets.

Key words: financial crisis, financial liquidity, refinancing operations

DOI: $10.15290 /$ ose.2015.02.74.03

\footnotetext{
${ }^{1}$ Dr hab. Jan Zarzecki, prof. WSE - Katedra Rachunkowości i Finansów, Wyższa Szkoła Ekonomiczna w Białymstoku; e-mail: jan.zarzecki@wse.edu.pl.
} 


\section{Wstęp}

Płynność makroekonomiczna (w skali całej gospodarki) może być wyprowadzona z sumy płynności poszczególnych podmiotów gospodarczych, gospodarstw domowych i instytucji publicznych. W takiej skali istnienie lub brak płynności nie mogą być ustalone i wymierzone. Trzeba więc zadowolić się uznaniem za reprezentatywny miernik płynności ogólnogospodarczej wskaźnik płynności banków komercyjnych, gdyż to one decydują o obiegu pieniężnym w gospodarce, zaopatrując podmioty pozabankowe w płynność. Zmiany płynności banków można zatem utożsamiać ze zmianą płynności ogólnogospodarczej [Schaal, 1996, s. 41].

Te monetarne instytucje finansowe zapewniaja podmiotom pozabankowym płynność, wykorzystując do tego celu rezerwy pieniężne zgromadzone na rachunkach tych podmiotów i własne kapitały. Aby przepływy towarów i usług mogły sprawnie przebiegać między podmiotami gospodarczymi, powinny być one zaopatrzone w pieniądz zapewniający im płynność finansową (zdolność płatnicza). Za jej utrzymanie odpowiedzialny jest bank centralny, dysponujący w tym zakresie określonymi uprawnieniami $i$ instrumentami. Celem opracowania jest zbadanie, czy Europejski Bank Centralny zdołał zapewnić płynność finansową Eurosystemu zaburzoną w czasie kryzysu finansowego. Warunki działania EBC w okresie kryzysu finansowego były nadzwyczajne, stąd konieczne było podejmowanie niestandardowych działań na rynkach finansowych.

Właśnie tym działaniom poświęcono analizę materiałów źródłowych i przegląd literatury. Jednak przedtem zostały opisane standardowe instrumenty zarządzania płynnością finansowa, będące w dyspozycji EBC celem zapoznania się $z$ istotą jego działalności w odniesieniu do badanego problemu. Zaprezentowano także przesłanki powstania kryzysu finansowego i jego oddziaływania na system finansowy strefy euro.

Badaniem objęto lata 2008-2012, gdyż na ten okres są opublikowane materiały statystyczne i analizy przez EBC. Podstawowym materiałem źródłowym były „Raporty Roczne" EBC. Do prezentacji informacji statystycznych wykorzystano graficzna technikę. Raporty zawierają dużą ilość informacji liczbowych, dlatego metoda ta jest najbardziej przejrzysta. Rysunki bowiem ilustrują znaczenie czynników zwiększających i absorbujących płynność, umożliwiając zdobycie ogólnej wiedzy o problemach występujących na rynkach finansowych strefy euro.

\section{Podstawowe instrumenty kształtowania płynności finansowej}

Płynność systemu bankowego określa zdolność banków komercyjnych do realizowania transakcji. Rozliczenia transakcji są dokonywane na rachunkach prowadzonych przez bank centralny. Płynność banków jest uzależniona zatem od stanu środków pieniężnych utrzymywanych na rachunkach w banku centralnym. Zmiany stanu środków pieniężnych na rachunkach banków w banku centralnym to zmiany płynności banków komercyjnych. Są one powodowane przez czynniki autonomiczne wobec instrumentów stosowanych przez bank centralny. Czynniki te pozostają poza wpływem banku centralnego, choć dotyczą jego bilansu. Jeśli układ czynników autonomicznych 
powoduje konieczność zasilania banków w pieniądz przez bank centralny, występuje niedobór płynności i wówczas bank centralny jest wierzycielem netto banków komercyjnych. W sytuacji, gdy układ czynników autonomicznych wywołuje potrzebę zmniejszenia zasobów pieniądza banków komercyjnych przez bank centralny, ma miejsce nadpłynność i bank centralny jest dłużnikiem banków komercyjnych.

Bank centralny może wpływać na płynność rynku pieniężnego, zachęcając banki komercyjne do uczestniczenia w operacjach na otwartym rynku. Rynek otwarty jest utożsamiany z międzybankowym rynkiem pieniądza, którego uczestnikami są banki komercyjne i bank centralny.

Eurosystem wykorzystuje podstawowe operacje refinansujące (MRO), dłuższe operacje refinansujące (LTRO) i operacje dostrajające do zarządzania poziomem płynności na rynku pieniężnym. W strefie euro występuje bowiem niedobór płynności, w odróżnieniu od Polski z nadmiarem płynności. Podstawowe operacje refinansujące są przeprowadzane regularnie w odstępach tygodniowych $\mathrm{z}$ terminem zapadalności jednego tygodnia. Są one głównym instrumentem sygnalizującym stanowisko $\mathrm{EBC}$ w polityce pieniężnej poprzez stope procentową tych operacji. Regularne, dłuższe operacje refinansujące dokonuje się comiesięcznie z trzymiesięcznym terminem zapadalności. Europejski Bank Centralny może przeprowadzać operacje dostrajające, zasilające w płynność lub ją absorbujące w trybie ad hoc w celu zarządzania poziomem płynności na rynku pieniężnym i sterowania poziomem stóp procentowych. Wszystkie operacje zasilające $\mathrm{w}$ płynność są w pełni zabezpieczone akceptowanymi przez bank centralny aktywami banków komercyjnych, najczęściej papierami wartościowymi.

Banki komercyjne mogą korzystać z depozytu jednodniowego w banku centralnym na koniec dnia, aby ulokować nadmiar płynności oraz kredytu w banku centralnym na koniec dnia w celu pozyskania jednodniowej płynności, pod warunkiem przekazania zabezpieczenia kwalifikowanego. Oprocentowanie tych transakcji określa maksymalny i minimalny poziom stopy procentowej jednodniowej overnight (EONIA). Korzystanie $z$ depozytów w banku centralnym na koniec dnia odbywa się według modelu polegającego na tym, że na początku każdego okresu utrzymywania rezerwy obowiązkowej kwoty są niskie i stopniowo wzrastają w miarę spełniania wymogów tej rezerwy (rysunek 4.). Ponadto banki moga korzystać w banku centralnym z bezpłatnego kredytu śróddziennego (intraday) wspierającego system płatniczy, również zabezpieczonego. Celem jest ułatwienie bankom zarządzania płynnością finansową w ciagu dnia operacyjnego. Instrument ten łagodzi wahania stóp procentowych wynikających z zaburzeń płynnościowych i przyczynia się do rozwoju rynku międzybankowego.

System rezerwy obowiązkowej spełnia dwie istotne funkcje. Po pierwsze, powoduje stabilizację stóp krótkoterminowych rynku pieniężnego, ponieważ wymogi w zakresie rezerwy obowiązkowej powinny być spełnione na poziomie średnim w okresie jej utrzymywania (około jednego miesiąca). Poza tym może ona być wykorzystywana w operacjach płatniczych, co umożliwia bankom łagodzenie przejściowych, nieoczekiwanych zmian poziomu płynności. Po drugie, zwiększa deficyt płynności systemu bankowego, czyli ogólne zapotrzebowanie banków na refinansowanie z Eurosystemu. Zapewnia tym samym przewidywalny popyt na refinansowanie, co ułatwia za- 
rządzanie krótkoterminowymi stopami procentowymi rynków pieniężnych Eurosystemu.

\section{Przesłanki postania kryzysu finansowego}

W sierpniu 2007 roku światowy system finansowy wszedł w okres poważnych zakłóceń spowodowanych wzrostem wskaźników niespłaconych kredytów hipotecznych podwyższonego ryzyka (subprime) w Stanach Zjednoczonych Ameryki. Zastosowana przez Fed w poprzednich latach (2000-2003) polityka taniego pieniądza doprowadziła do zalania światowego rynku tanim dolarem. Skutkiem nadpłynności w systemie bankowym były tanie kredyty, w tym również hipoteczne, tworzące rzekomo klasę średnią w USA. Była to próba spełnienia amerykańskiego marzenia związana z tym, aby dać ludziom kredyt na własny dom, samochód, kartę kredytowa. Przeznaczono go osobom bez konieczności posiadania dobrej historii kredytowej, nieposiadającym stałego źródła dochodu i majątku.

Uruchomienie mechanizmu ekspansji kredytowej przyniosło wzrost popytu na kredyty hipoteczne i wzrost cen nieruchomości. Wzrost cen stymulował popyt, który z kolei pobudzał wzrost cen. Wytworzyła się bańka spekulacyjna. Refinansowanie akcji kredytowej następowało w formie emisji obligacji zabezpieczonych kredytami hipotecznymi (w Polsce listy zastawne), w tym także kredytami podwyższonego ryzyka. Kredyty subprime były łączone przez firmy inwestycyjne w pakiety, przekształcane w obligacje i oferowane bankom na całym świecie. Ryzyko tych kredytów przejęli na siebie inni uczestnicy rynku finansowego nabywający obligacje. Papiery te miały skomplikowaną i niejasną konstrukcję oraz były pozbawione ceny rynkowej tych instrumentów, nie były bowiem przedmiotem zorganizowanego obrotu na rynkach finansowych.

Dynamicznie rozwijały się instrumenty pochodne (derywaty), które spotęgowały efekt domina na rynku nieruchomości w USA; wartość derywatów w 1998 roku wynosiła 72 bln dolarów, a w 2008 roku 683 bln dolarów. Skutkiem tego było wykreowanie wirtualnego pieniądza. Jego przyrost, napędzany chęcią wysokiego zysku, motywował do podejmowania coraz bardziej ryzykownych strategii inwestycyjnych [Paździor, 2013, s. 69].

Gdy Fed podniósł stopniowo główną stopę procentową Rezerwy Federalnej z 1\% w 2004 roku do 5,25\% w sierpniu 2006 roku, zaczęły się poważne problemy ze spłaceniem kredytów przez kredytobiorców. Spowodowało to oczekiwany spadek hossy na rynku nieruchomości, a następnie dramatyczny spadek cen nieruchomości. Rezultatem było obniżenie wartości zabezpieczeń, co w połączeniu z trudnościami w spłacie tych kredytów uruchomiło zmniejszenie zaufania do obligacji wyemitowanych na podstawie tych kredytów. Inwestorzy wycofywali się z uczestnictwa w strukturyzowanych funduszach inwestycyjnych (SIV) i ze spółek inwestycyjnych utworzonych przez banki, opartych na papierach wartościowych zabezpieczonych aktywami pochodzacymi z sekurytyzacji kredytów hipotecznych podwyższonego ryzyka w Stanach Zjednoczonych. W miarę narastania niepokoju banków w odniesieniu do ich płynności i bilan- 
sów, coraz powściagliwiej pożyczały sobie pieniądze w ramach finansowania międzybankowego. Zaczęły zatrzymywać płynność sobie. Międzybankowy rynek pieniądza zmniejszył swoją płynność. Występujące zakłócenia utrudniały bankom uzyskanie finansowania na rynku pieniężnym.

W połowie września 2008 roku rozpoczął się burzliwy okres, gdy w ciagu zaledwie kilku dni uczestnicy rynków finansowych obserwowali jak swe aktywa wyprzedawał bank Merryl Lynch, upadł bank Lehman Brothers (dwa z czterech globalnych banków inwestycyjnych), rząd USA awaryjnie dokapitalizował AIG - czołowego amerykańskiego ubezpieczyciela, a federalna agencja regulacyjna przejęła Washington Mutual - największą kasę oszczędnościowo-kredytową w USA².

Warunki gospodarcze na świecie szybko pogorszyły się i taniały nieruchomości, gwałtownie traciły na wartości akcje, zaostrzono warunki kredytowania, powstawały więc niekorzystne efekty majątkowe. Pod koniec 2008 roku najbardziej rozwinięte gospodarki znalazły się w recesji lub na jej krawędzi. Upadek największego banku inwestycyjnego USA pociagnął za sobą wielu pierwszoplanowych aktorów światowego systemu finansowego, którzy stracili aktywa zainwestowane u bankruta (straty $28 \mathrm{mld}$ USD), także z krajów strefy euro. Lehman Brothers, choć był amerykańskim bankiem, to w dużej części obsługiwał podmioty zagraniczne, szczególnie banki azjatyckie i europejskie. Podobna jak w USA sytuacja na rynku nieruchomości występowała również w wielu rozwiniętych krajach europejskich, w których był widoczny wzrost wolumenu transakcji sekurytyzacyjnych. Wzrosły one z około 10 mld euro w 2000 roku do ponad 90 mld euro w 2007 roku, w tym zwłaszcza w Wielkiej Brytanii [Paździor, 2013, s. 67]. Ponadto miał miejsce spekulacyjny wzrost cen surowców na rynkach światowych, przede wszystkim energetycznych. Cena ropy naftowej wzrosła ze 100 USD za baryłkę w styczniu 2008 roku do 150 USD w lipcu, a od września zaczęła spadać do 40 USD za baryłkę w grudniu.

Rynki pieniężne doznały dalszych napięć w wyniku pogorszenia się otoczenia makroekonomicznego. Stopy procentowe niezabezpieczonych transakcji rynku pieniężnego wzrosły, pojawiły się poważne zakłócenia i niedobór płynności finansowej. Rozszerzający się brak zaufania między bankami doprowadził praktycznie do zaprzestania operacji na rynkach międzybankowych. Na skutek zaburzeń we wrześniu i październiku 2008 roku banki gwałtownie zwiększyły potrzeby płynnościowe.

\section{Zwiększanie płynności finansowej przez Europejski Bank Centralny}

Rządy i banki centralne na całym świecie podejmowały działania ograniczające ryzyko systemowe $^{3}$, by poprawić stabilność na rynkach finansowych. Reakcja na pogarszające się wskaźniki makroekonomiczne w końcu 2008 roku były duże obniżki stóp procentowych przez władze monetarne największych państw. Sytuacja na rynku kredytowym nie

\footnotetext{
2 Lączna kwota strat 13 największych banków USA wyniosła 285 mld USD [Al Kaber, 2009, s. 62].

${ }^{3}$ Ryzyko systemowe - niezdolność jednego uczestnika systemu do wykonania zobowiązań powoduje, że inni uczestnicy nie będą mogli wykonać zobowiązań, co może doprowadzić np. do znacznych problemów kredytowych niepłynnościowych, zagrażających stabilności systemu finansowego.
} 
poprawiła się. Polityka pieniężna w USA, Japonii i Wielkiej Brytanii nie osiagnęła oczekiwanych efektów. Władze monetarne tych państw zaczęły stosować tzw. luzowanie ilościowe, czyli zasilanie systemu finansowego dodrukowanym pieniądzem przez skupywanie najbardziej płynnych obligacji skarbowych i korporacyjnych.

Luzowanie ilościowe (quantitative easing - QE) jest polityką pieniężną mającą na celu zwiększenie podaży pieniądza przez wzrost bilansu banku centralnego, zwłaszcza przez zakup obligacji skarbowych. Ryzyko systemowe związane z mała płynnością na rynkach lub zapaścią kredytów jest mniejsze dzięki QE. Wzrasta dostępność kredytów, rośnie PKB i spada bezrobocie. Skup obligacji powoduje obniżkę długoterminowych stóp procentowych. Jednocześnie QE jest krytykowane za zwiększanie globalnej inflacji i prowokowanie baniek spekulacyjnych na skutek dużych kwot „pustego pieniądza" [Płukarz, 2012, s. 365].

Europejski Bank Centralny nie przeprowadzał operacji luzowania ilościowego, ale stosował od 2009 roku instrumenty zbliżone charakterem i skutkiem do QE. W odróżnieniu od QE były to operacje sterylizowane, gdyż nadwyżki gotówki były ściagane z rynku przez bank centralny, nie zwiększając poziomu inflacji, której zwalczanie jest głównym celem.

Działania Europejskiego Banku Centralnego w czasie kryzysu można ujać w trzech punktach:

1) Stabilizacja cen poprzez politykę stóp procentowych - główny cel;

2) Zasilanie Eurosystemu w płynność;

3) Normalizacja sytuacji na wtórnym rynku długu krajów PIIGS.

Drugi i trzeci cel ograniczają osiagnięcie celu pierwszego, dlatego EBC stosował operacje absorbujące. Ze względu na poważne utrudnienia w funkcjonowaniu systemu finansowego, od 8 października 2008 roku EBC wprowadzał wiele różnych zmian do swoich podstawowych zasad uruchamiania płynności finansowej, starając się szczególnie umocnić funkcje pośrednika i zabezpieczyć rynki przed ryzykiem płynności. Stąd wprowadził pięć dodatkowych rozwiązań w zakresie zarządzania płynnością.

1. Dostarczenie bankom strefy euro nieograniczonych kwot płynności. Wszystkie podstawowe i dłuższe operacje przeprowadzono jako przetargi kwotowe (po stałej stopie procentowej) z pełnym przydziałem. Podaż pieniądza określono przez łączną kwotę zapotrzebowania kontrahentów, realizowano bowiem wszystkie oferty. Celem tego działania było zasygnalizowanie uczestnikom rynku, że EBC jest gotowy dostarczyć potrzebne pieniądze, by uniknąć wystapienia kryzysu w zakresie płynności. Jednocześnie znacznie (o 175 punktów bazowych) obniżono podstawową stopę procentowa EBC (rysunek 1.). Wynikało to z zasady - jeżeli bank centralny zwiększa ilość pieniądza na rynku powinien obniżyć adekwatnie stopy procentowe, aby zwiększyć na niego popyt i na odwrót - zmniejszaniu ilości pieniądza powinno towarzyszyć podwyższanie stóp procentowych zmniejszające popyt.

Doprowadziło to do znacznego wzrostu łącznego wolumenu nierozliczonych operacji otwartego rynku denominowanych w euro (rysunek 2.). Zapewnianie większej płynności znacznie zmniejszyło napięcie na rynku pieniężnym instrumentów krótkoterminowych i spowodowało spadek stopy procentowej 
EONIA. Utrzymywała się ona na poziomie znacznie niższym od stopy podstawowych operacji refinansujących, gdy dotychczas oscylowała wokół tej stopy (rysunek 1.).

2. Podjęto decyzję o zmniejszeniu korytarza tworzonego przez dwie operacje EBC na koniec dnia (kredytu i depozytu) z 200 do 100 punktów bazowych (rysunek 1.). Celem było ułatwienie zarządzania płynnością przez banki dzięki taniemu pośrednictwu banku centralnego bankom komercyjnym.

3. Wprowadzono dodatkowe dłuższe operacje refinansujące o zapadalności trzech miesięcy i sześciu miesięcy; zapewniono je dzięki rolowaniu istniejących i uruchamianiu nowych operacji (rysunek 3.).

4. Dostarczono płynność w walutach obcych. Zwiększono płynność w dolarach USA poprzez dodatkowe operacje $z$ siedmiodniowym terminem zapadalności, a następnie operacje jednodniowe w połączeniu $\mathrm{z}$ istniejącymi dwudziestoośmiodniowymi i osiemdziesięcioczterodniowymi. Działanie to podejmowano we współpracy z Systemem Rezerwy Federalnej (FED) USA w ramach umowy swapowej (pożyczka w dolarach zabezpieczona euro).

\section{RYSUNEK 1.}

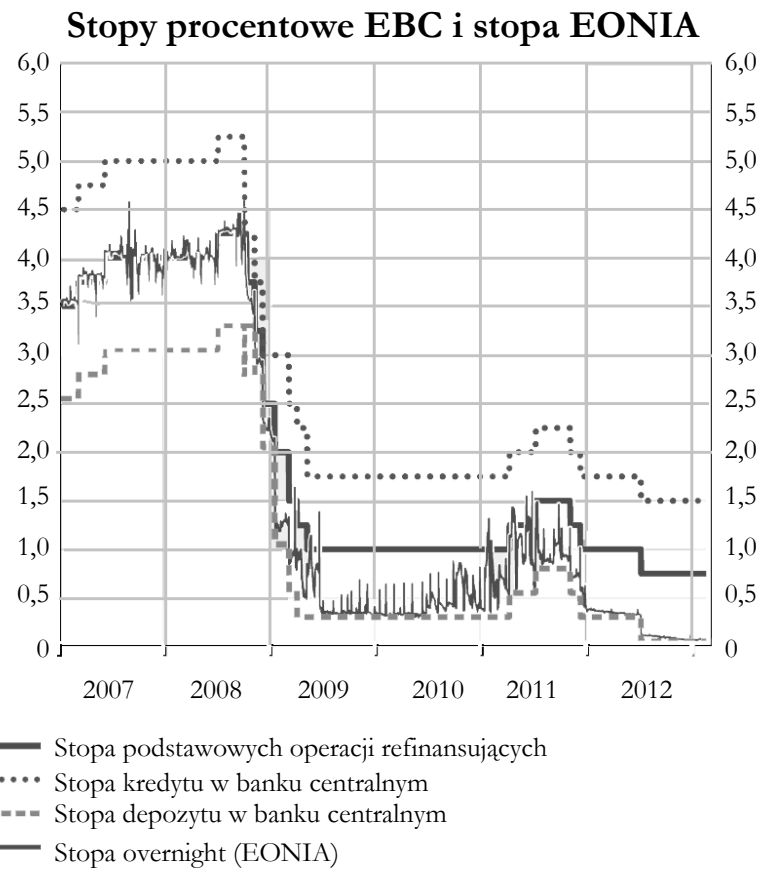

Oprocentowanie roczne, dane dzienne.

Źródło: [Raport Roczny..., 2012, s. 14].

Narodowy Bank Szwajcarii i EBC również podjęły wspólne działania zwiększające płynność we frankach szwajcarskich przez linię swapową (swapy 
walutowe EUR/CHF po stałej cenie i przy maksymalnej stopie przydziału). Operacje te mają odzwierciedlenie w bilansie Eurosystemu (rysunek 2.).

5. Rozszerzono listy aktywów akceptowanych jako zabezpieczenie pod koniec 2008 roku. Wystarczające zabezpieczenie było dostępne stronom transakcji, aby Eurosystem mógł zapewnić kwotę płynności uznanej za niezbędną w działaniach polityki pieniężnej. Toteż akceptowano szeroką gamę aktywów, które mogły być zabezpieczeniem w operacjach kredytowych. W ten sposób Eurosystem był w stanie zapewnić wymaganą płynność umożliwiająca reakcję na gorsze funkcjonowanie rynku pieniężnego, nie napotykając na szeroko rozpowszechnione ograniczenie w zakresie zabezpieczeń podczas kryzysu finansowego. Eurosystem przyjmował:

- instrumenty emitowane przez banki, w tym certyfikaty depozytowe nienotowane na rynku regulowanym, ale akceptowane przez EBC;

- zbywalne instrumenty dłużne wyemitowane w strefie euro, denominowane w: dolarach, funtach szterlingach i jenach japońskich, gdy emitent ma siedzibę w Europejskim Obszarze Gospodarczym.

Rozszerzeniu zestawu kwalifikowanych zabezpieczeń towarzyszyło zastosowanie środków kontroli ryzyka finansowego dzięki uważnemu monitorowaniu wykorzystania tych zabezpieczeń [Raport Roczny..., 2008, s. 113-115].

Powyższe działania miały na celu opanowanie zaburzeń na rynku pieniężnym i stymulowanie procesu przekładania się obniżek stóp procentowych EBC na poziom stóp procentowych rynku pieniężnego i kredytów bankowych. Miało to spowodować poprawę warunków finansowania i pobudzić napływ kredytów do gospodarstw domowych i przedsiębiorstw. Program nadzwyczajnego wsparcia kredytowego był skierowany do banków, ponieważ to one są podstawowym źródłem finansowania sfery realnej w strefie euro [Mucha-Leszko, 2011, s. 192].

Dostarczając płynność poprzez operacje otwartego rynku, Eurosystem uwzględnia codzienną ocenę zapotrzebowania na płynność ze strony systemu bankowego strefy euro w ujęciu zagregowanym. Zapotrzebowanie na płynność odpowiada sumie rezerw obowiązkowych utrzymywanych przez banki, środków przekraczających wysokość rezerwy obowiązkowej utrzymywanych na rachunkach bieżących instytucji kredytowych w Eurosystemie (nadwyżek rezerw) oraz czynników autonomicznych. Czynniki autonomiczne są pozycjami bilansowymi Eurosystemu, takimi jak banknoty w obiegu oraz depozyty instytucji rządowych, które wpływaja na poziom środków utrzymywanych na rachunkach bieżących instytucji kredytowych, lecz nie są bezpośrednio objęte procesami zarządzania płynnością Eurosystemu.

Europejski Bank Centralny w swoich komunikatach podkreślał, jak istotne znaczenie dla funkcjonowania rynków ma utrzymywanie oddzielenia decyzji polityki pieniężnej od zarządzania płynnościa. Polityka pieniężna była ukierunkowana w stronę realizacji celu stabilności cen, a zarządzanie płynnością zmierzało do zapewnienia ciagłości prowadzonej działalności i płynnego funkcjonowania rynków pieniężnych. 
pozioma 
W wyniku tych działań bilans Eurosystemu znacznie wzrósł i zmienił strukturę. Suma bilansowa zwiększyła się z około 950 mld euro we wrześniu 2008 roku do około 1750 mld euro w czerwcu 2010 roku. Po stanie aktywów najbardziej wzrosły transakcje w dolarach amerykańskich i program zakupu obligacji skarbowych zabezpieczonych. Po stronie pasywów wzrosły pożyczki w banku Centralnym Szwajcarii i Rezerwie Federalnej USA (rysunek 2.). Analiza bilansu daje ogólny pogląd na znaczenie i rozmiary poszczególnych działań EBC, które poddano analizie również w dalszej części opracowania.

W 2009 roku nadal stosowano rodzaje operacji refinansujących, wprowadzone w poprzednim roku: dodatkowe dłuższe operacje $z$ trzymiesięcznym i sześciomiesięcznym terminem zapadalności i operacje STRO z okresem zapadalności równym długości okresu utrzymywania rezerwy obowiązkowej. Ponadto miały miejsce trzy dłuższe operacje refinansujące zasilające w płynność z okresem zapadalności jednego roku. Wszystkie operacje były przeprowadzone w formie procedur z pełnym przydziałem.

Na 31 grudnia 2009 roku roczne operacje refinansujące stanowiły $82 \%$ całkowitej kwoty refinansowania, podstawowe operacje refinansujące $-11 \%$, operacje $z$ trzymiesięcznym lub sześciomiesięcznym okresem zapadalności odpowiednio - 3\% i 4\%. Program zakupu operacji zabezpieczonych stanowił $4 \%$ operacji zasilających w płynność [Raport Roczny..., 2009, s. 111].

Kwoty przydzielone w operacjach refinansujących istotnie przekroczyły zapotrzebowanie na płynność skonsolidowanego systemu bankowego strefy euro. Nadwyżki banki składały w formie depozytów w Eurosystemie, płacąc oprocentowanie stałe według stopy podstawowych operacji refinansujących i otrzymując oprocentowanie stałe według stopy dla depozytów w banku centralnym na koniec dnia. Kontynuowano więc sytuację występującą w 2008 roku (rysunek 3.). Implikowało to różnicę w wysokości 100 punktów bazowych przed 13 maja 2013 roku i 75 punktów bazowych po tej dacie. Świadczy to o zapobiegawczym popycie na płynność z Eurosystemu występującym u kontrahentów, będącym „składką” na ubezpieczenie płynności.

W pierwszej połowie 2009 roku EBC obniżył oprocentowanie podstawowych operacji refinansujących czterokrotnie o 150 punktów bazowych, a łączna suma dokonanych obniżek od października 2008 roku wyniosła 325 punktów bazowych (rysunek 1.).

Zastosowanie powyższych środków istotnie wpłynęło na obniżenie stóp procentowych rynku pieniężnego, gdyż na dłuższy czas zapewniało bankom łatwy i tani dostęp do dużych zasobów płynności. Przyczyniło się także do złagodzenia ryzyka dotyczącego finansowania banków.

W związku z dużą ilością płynności dostarczonej bankom stopa overnight (EONIA) była zbliżona do oprocentowania depozytów w banku centralnym, gdy przed kryzysem finansowym oscylowała wokół stopy procentowej podstawowych operacji refinansujących (rysunek 1.). 
RYSUNEK 3.

Podaż płynności: operacje otwartego rynku i wykorzystanie kredytu i depozytu w banku centralnym na koniec dnia w 2008 r. (mld euro)

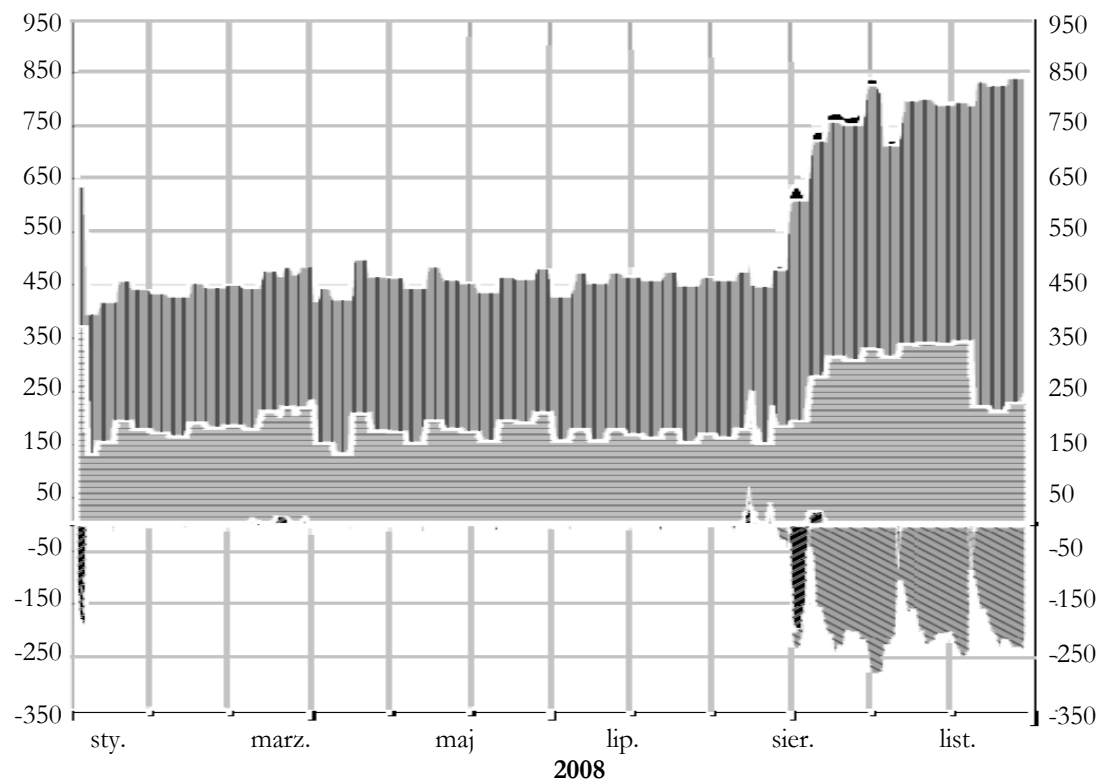

Kredyt z banku centralnego na koniec dnia
Dłuższe operacje refinansujące
Podstawowe operacje refinansujące
Operacje dostrajające
Depozyt z banku centralnego na koniec dnia

Źródło: [Raport Roczny..., 2008, s. 113].

Pomimo tych wysiłków, występująca w 2008 roku recesja od początku 2009 roku przeszła w gwałtowny spadek gospodarczy; w 2009 roku realny PKB strefy euro obniżył się o 4,1\% po wzroście o 0,5\% w 2008 roku.

Pozytywne zmiany w funkcjonowaniu rynku pieniężnego odnotowane w 2009 roku spowodowały, że od początku 2010 roku EBC stopniowo wycofywał wsparcie płynnościowe, które nie było już potrzebne w takim zakresie, jak wcześniej. Zaprzestano stosowania dłuższych operacji refinansujących. W porozumieniu $z$ innymi bankami centralnymi zaprzestano również prowadzenia tymczasowych operacji zasilających w płynność w walutach obcych. W czerwcu, gdy wartość zakupionych przez Eurosystem obligacji zabezpieczonych denominowanych w euro osiagnęła $60 \mathrm{mld}$ euro, zakończono program skupu obligacji wprowadzony w maju 2009 roku na okres jednego roku. Eurosystem nadal dostarczał systemowi bankowemu strefy euro nadzwyczajnego wsparcia płynnościowego z pełnym przydziałem w podstawowych operacjach refinansujących, pobudzając $\mathrm{w}$ ten sposób napływ kredytów do gospodarki (rysunek 4.). W rezultacie stopa procentowa EONIA utrzymywała się na poziomie zbli- 
żonym do stopy depozytu w banku centralnym, na którym utrzymywała się od października 2008 roku, kiedy wprowadzono tryb przetargu kwotowego z pełnym przydziałem. Jednocześnie była ona stabilna, gdyż przez cały rok EBC nie zmieniał podstawowych stóp procentowych (rysunek 1.).

Jednakże od 7 maja 2010 roku ponownie pojawily się napięcia na rynkach finansowych. Szczególnie napięta była sytuacja na niektórych rynkach obligacji skarbowych. $\mathrm{Na}$ początku obecnego kryzysu finansowego konieczność ratowania wypłacalności systemowej banków zmuszała rządy wielu państw do ich wsparcia środkami publicznymi, pozyskiwanymi przez dodatkowe zadłużenie. Wysokie deficyty finansów publicznych, szybko rosnące wskaźniki długu publicznego do PKB i zwiększające się zobowiązania z tytułu gwarancji udzielonych bankom doprowadziły do nasilenia się kryzysu finansowego.

Wobec nadmiernej emisji obligacji skarbowych wzrosła ich rentowność (spadek cen), co wpłynęło negatywnie na sytuację banków, które posiadały najwięcej obligacji rządowych. Wystapiła II faza kryzysu gospodarczego na świecie, polegająca na negatywnym oddziaływaniu kryzysu finansów publicznych powyższych państw [Polityka ekonomiczna..., 2013, s. 121]. Natomiast osiagnęły wartości nienotowane od czasu wprowadzenia euro w 1999 r. W takiej sytuacji rządy państw strefy euro uchwaliły pakiet środków zaradczych, w tym utworzenie spółki European Stability Facility. Celem tego programu było zasilanie w płynność segmentów rynku niefunkcjonujących właściwie i przywrócenie prawidłowej transmisji impulsów polityki pieniężnej.

Europejski Bank Centralny przedstawił program dotyczący rynku papierów wartościowych jako nową inicjatywę mająca niwelować te napięcia. Przede wszystkim należało zmniejszyć podaż obligacji, aby wzrosły ich ceny. Zgodnie z przepisami traktatu, transakcje zakupu obligacji skarbowych przeprowadzano na rynku wtórnym, wzrost zasobu płynności dostarczanej przez program absorbowano przez cotygodniowo przyjmowane depozyty od banków o stałej stopie procentowej, gdyż celem tego programu nie jest zwiększenie płynności systemu bankowego. Operacje te powodowały zdjęcie $z$ rynku nadmiaru obligacji i transfer płynności do banków je sprzedających z banków uczestniczących w operacjach zmniejszających płynność. Faktycznie pośredniczył tylko w przepływie płynności między bankami bez zmiany jej wielkości. Na koniec 2010 roku kwota interwencji na rynkach obligacji wyniosła 73,5 mld euro, tyle co zasoby płynności zaabsorbowanej z rynku pieniężnego.

W 2010 roku system bankowy strefy euro w dalszym ciagu pożyczał kwoty przekraczające zapotrzebowanie na płynność i składał je w formie depozytów w Eurosystemie, płacąc oprocentowanie stałe według stopy podstawowych operacji refinansujących i otrzymując oprocentowanie według stopy depozytu w banku centralnym na koniec dnia, co implikowało różnicę 75 punktów bazowych. Jednakże wielkość tych depozytów znacznie zmniejszyła się w drugim półroczu, co było wynikiem zmniejszenia dłuższych operacji refinansujących (rysunek 4.). 
RYSUNEK 4.

\section{Czynniki wpływające na płynność w strefie euro w 2010 roku (mld euro)}

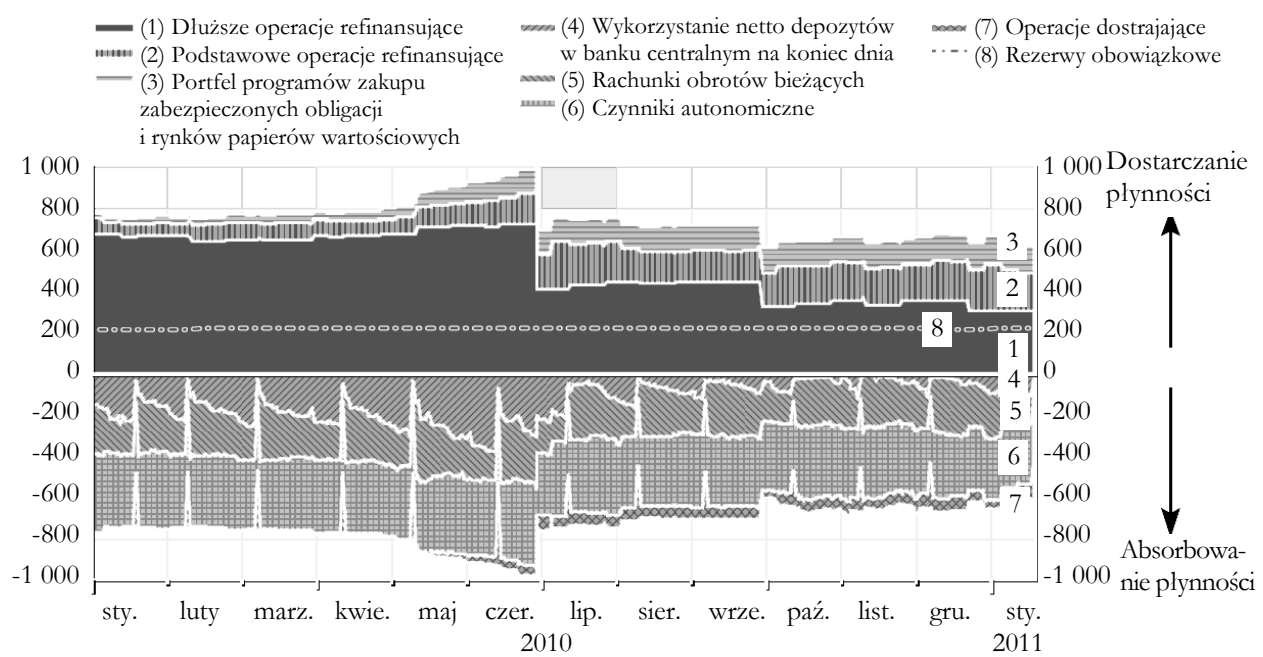

Źródło: opracowanie własne na podstawie: [Raport Roczny..., 2010, s. 102].

RYSUNEK 5.

\section{Czynniki wpływające na płynność w strefie euro w 2011 r. (mld euro)}

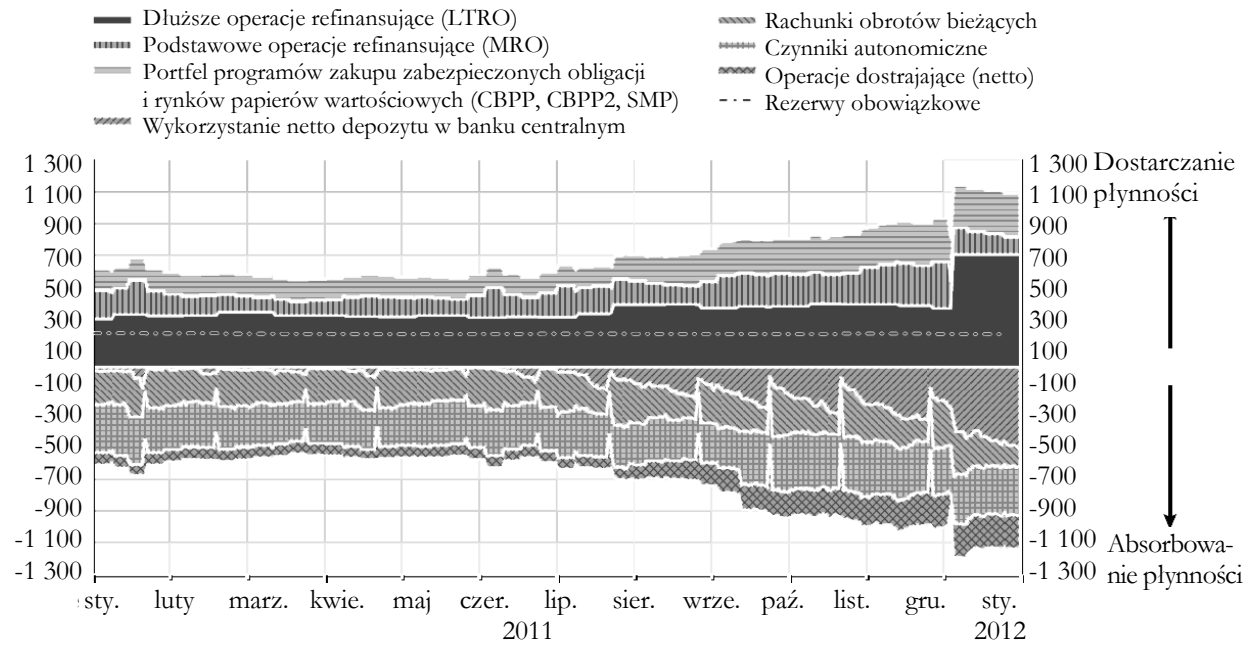

Źródło: [Raport Roczny..., 2011, s. 85]. 
W 2011 roku Eurosystem działał w bardzo trudnych warunkach. Z powodu podwyżek cen surowców występowała presja inflacyjna. Chociaż z analizy ekonomicznej wynikało, że tendencja podaży pieniądza jest umiarkowana, to zasoby płynności pieniężnej były tak duże, że powstawały warunki wzrostu cen. Aby im zapobiec, EBC dwukrotnie - w kwietniu i lipcu - podniósł podstawowe stopy procentowe łącznie o 50 punktów bazowych.

W drugim półroczu nasiliły się napięcia na rynkach finansowych, osłabiając aktywność gospodarczą w strefie euro. Były one związane z obligacjami skarbowymi i wynikały głównie z obaw uczestników rynku finansowego dotyczaccych: perspektyw wzrostu gospodarczego na świecie, stabilności finansów publicznych niektórych krajów strefy euro (szczególnie: Grecji, Portugalii, Irlandii, Hiszpanii, Włoch) oraz reakcji rzadów na kryzys zadłużeniowy, uważanej za niewystarczająca. Ponadto pojawiła się niepewność dotycząca warunków wspólnotowej pomocy finansowej krajom najbardziej dotkniętym kryzysem zadłużeniowym, w tym ewentualnego w nim udziału podmiotów finansujących potrzeby pożyczkowe. Koszty obsługi zadłużenia finansów publicznych były dodatkowo obciążone wzrostem oprocentowania (spadkiem cen) obligacji skarbowych nienotowanym od powstania strefy euro w 1999 roku.

Aby zapewnić płynną i równomierną transmisję impulsów polityki pieniężnej do gospodarki, nadal interwencyjnie skupowano skarbowe dłużne papiery wartościowe w ramach programu SMP rozpoczętego w maju 2010 roku w wyżej wymienionych krajach. Do końca 2011 roku zakupiono papiery wartościowe na kwotę 144,6 mld euro, a od początku realizacji programu o wartości 211,4 mld euro [Raport Roczny..., 2011, s. 81].

W październiku 2011 roku EBC zainicjował nowy program zakupu obligacji skarbowych (CB PP2). Uruchomiono go, by złagodzić warunki finansowania bankom i spó1kom oraz zachęcić banki do rozwijania akcji kredytowej. Zakupy prowadzono na rynkach pierwotnych (nowość) i wtórnych. Pełne wdrożenie programu planowano do końca października 2012 roku. Bezpośrednie wspieranie rządów przez EBC, np. przez zakup obligacji na rynku pierwotnym jest prawnie zabronione, stąd program realizowano naruszając prawo.

W listopadzie i grudniu EBC obniżył podstawowe stopy procentowe łącznie o 50 punktów bazowych, powróciły one do stanu z początku roku. Przedział oprocentowania wynosił 150 punktów bazowych (75 punktów bazowych po każdej ze stron operacji MRO - rysunek 1.).

Europejski Bank Centralny determinował działania na rzecz łagodzenia napięć w niektórych segmentach rynków finansowych. Operacje MRO i LTRO w dalszym ciagu przeprowadzano w formie przetargów o stałej stopie procentowej z pełnym przydziałem środków. Saldo operacji refinansujących kształtował popyt ze strony kontrahentów, odzwierciedlając ich preferencje w zakresie płynności. W pierwszej połowie 2011 roku system bankowy ustabilizował zapotrzebowanie na płynność z Eurosystemu w wysokości około 600 mld euro, zwiększył je gwałtownie w drugim półroczu do około 1,1 biliona euro do końca roku (rysunek 5.).

W 2011 roku średnie dzienne zapotrzebowanie systemu bankowego na płynność wynosiło 470 mld euro, czyli o 16\% mniej niż 2010 roku [Raport Roczny..., 2011, s. 84]. 
Na liście zabezpieczeń kwalifikowanych, oprócz zabezpieczeń zbywalnych, znalazły się dodatkowo aktywa niezbywalne, głównie należności kredytowe (kredyty bankowe) oraz depozyty terminowe.

W związku ze znacznymi nadwyżkami płynności (tj. różnicą między płynnością dostarczana przez Eurosystem a zapotrzebowaniem systemu bankowego na płynność) zwiększyło się wykorzystanie depozytu w banku centralnym na koniec dnia. W pierwszym półroczu średnie wykorzystanie tego instrumentu wynosiło 25 mld euro i wzrosło do 528 mld euro pod koniec dwunastego okresu utrzymywania rezerw w $2011 \mathrm{roku}^{4}$ (por. rysunek 5.). Jest to suma istotna w dokapitalizowaniu banków Unii Europejskiej i operacje te należy ocenić bardzo pozytywnie [Polityka ekonomiczna..., 2013, s. 118].

Dnia 15 września, w wyniku pojawienia się problemów z finansowaniem dolarowym, EBC zapowiedział trzy operacje zasilające w płynność w USD z terminami zapadalności trzech miesięcy, w uzgodnieniu z innymi bankami centralnymi. Były to transakcje repo z zabezpieczeniem kwalifikowanym. Dnia 8 grudnia EBC zapowiedział dodatkowe środki zwiększające płynność na rynku pieniężnym. Podjęto decyzję o przeprowadzeniu dwóch dłuższych operacji refinansujących z trzyletnim terminem zapadalności, z możliwością wcześniejszej spłaty po upływie jednego roku. Przeprowadzono je 21 grudnia 2011 roku i 29 lutego 2012 roku, o łącznej wartości ponad 1 bln euro (rysunek 5.). Jest to suma istotna w dokapitalizowaniu banków Unii Europejskiej i operacje te należy ocenić bardzo pozytywnie [Polityka ekonomicznna..., 2013, s. 118].

Zasilanie w płynność miało również skłonić banki do dalszego nabywania obligacji krajów PIIOS (zwłaszcza włoskich i hiszpańskich), co częściowo się udało. Jednak większość kwot, zamiast trafić na kredytowanie europejskich przedsiębiorstw, została z powrotem ulokowana na jednodniowych depozytach [Płókarz, 2012, s. 331].

W 2012 roku Europejski Bank Centralny działał w niezwykle trudnych warunkach. Przedłużający się kryzys zadłużeniowy niektórych krajów Eurosystemu i poczucie, że rządy nie wykazują determinacji w zwalczaniu fundamentalnych przyczyn tego kryzysu, niekorzystnie oddziaływały na nastroje na rynkach finansowych. Niektóre rynki obligacji mocno odczuły nadmierny wzrost premii za ryzyko w połowie roku, wynikający między innymi z bezpodstawnych obaw dotyczących możliwości rezygnacji z euro. Przyczyniło się to do nasilenia problemów z finansowaniem, które już wcześniej występowały w systemie bankowym; niektóre banki utraciły dostęp do rynku międzybankowego i innych rynków finansowych. System bankowy zwiększył gwałtownie zapotrzebowanie na płynność z Eurosystemu.

Aby złagodzić niekorzystny wpływ napięć na rynkach finansowych, gospodarkę i podaż pieniądza, w lipcu 2012 roku EBC obniżł podstawowe stopy procentowe o 25 punktów bazowych i przez druga połowę roku pozostawały one na rekordowo niskim poziomie: stopa podstawowych operacji refinansujących $-0,75 \%$, stopa depozytu w banku centralnym - 0, stopa kredytu w banku centralnym - 1,5\% (rysunek 1.). Spowodowało to dalszy spadek stóp procentowych rynku pieniężnego, także jako skutek dwóch cięć po 25 punktów bazowych przeprowadzonych pod koniec 2011 roku.

\footnotetext{
${ }^{4}$ Etap ten objął 12 okresów utrzymania rezerw od 19 stycznia 2011 roku do 17 stycznia 2012 roku.
} 
RYSUNEK 6.

\section{Czynniki wpływające na płynność w strefie euro w 2012 r. (mld euro)}

Dłuższe operacje refinansujące (LTRO)
Podstawowe operacje refinansujące (MRO)
Programy zakupu zabezpieczonych obligacji i rynków
papierów wartościowych (CBPP, CBPP2, SMP)
Wykorzystanie netto depozytu w banku centralnym awa Rachunki obrotów bieżących
Czynniki autonomiczne
- Operacje dostrajające (netto)
- Rezerwy obowiązkowe

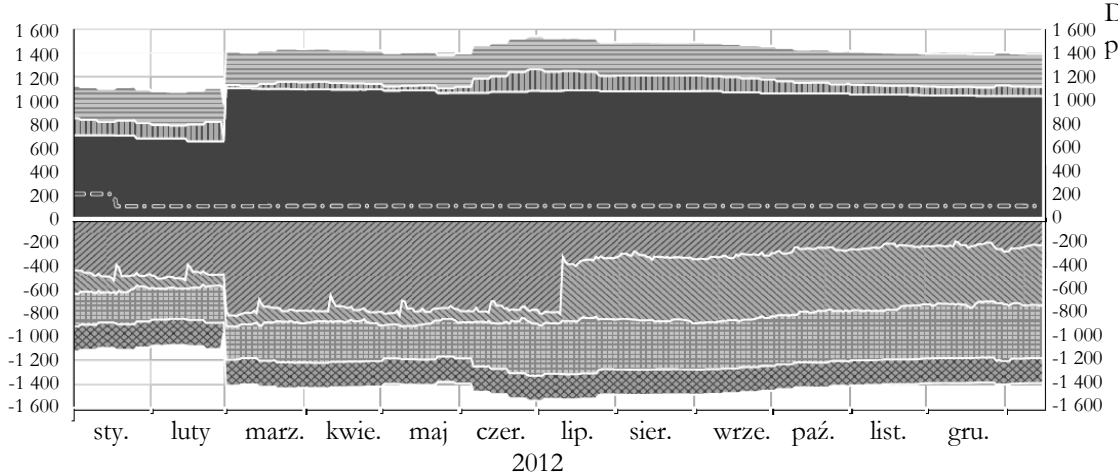

Dostarczanie

płynności

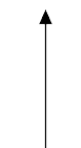

Absorbowanie płynności

Źródło: [Raport Roczny..., 2012, s. 85].

Podejmowano działania podażowe, zapewniające pokrycie zwiększonego popytu na pieniądz. W dalszym ciagu wszystkie operacje refinansujące dostarczające płynność przeprowadzano w formie przetargów o stałej stopie procentowej z pełnym przydziałem środków. Poziom operacji refinansujacych nadal kształtował popyt ze strony kontrahentów, co odzwierciedlało ich preferencje w zakresie zarządzania własną płynnością finansowa. Szczególnie duże znaczenie miały dwie dłuższe operacje refinansujace $\mathrm{z}$ terminem trzyletnim zapowiedziane 8 grudnia 2011 roku; 21 grudnia 2011 roku - 489,2 mld euro, 29 lutego 2012 roku - 529,5 mld euro. W rezultacie w 2012 roku calkowite zapotrzebowanie systemu bankowego na płynność osiagnęło 1,2 bln euro (rysunek 6.).

Operacje te, wraz z reformami przeprowadzonymi w niektórych krajach strefy euro, przyczyniły się do poprawy otoczenia finansowego na początku 2012 roku i do łagodzenia napięć na rynkach pieniężnych przez cały rok.

Po stosunkowo stabilnym początku 2012 roku warunki na rynkach długu państwowego w połowie roku znów pogorszyły się. Wynikało to głównie z przekonania, że rządy nie wykazują determinacji w podejmowaniu działań koniecznych do rozwiązania kryzysu i wdrożenia porozumień zawartych na szczeblu Wspólnoty Europejskiej. Obawiano się skutków niepewnej sytuacji w Grecji i wydarzeń w Hiszpanii i we Włoszech w odniesieniu do stabilności długu państwowego i ograniczonego dostępu do rynku jego finansowania. W krajach tych od lipca 2012 roku wzrosły ceny zwrotnych środków budżetowych wpływające na koszty obsługi zadłużenia. 
Przeciwdziałając zaburzeniom w wycenie długu państwowego, EBC ogłosił w sierpniu 2012 roku, że jest gotów przeprowadzić bezwarunkowe transakcje monetarne (OMT) na wtórnych rynkach obligacji skarbowych w strefie euro. Płynność powstała wskutek tych transakcji miała być w pełni sterylizowana, jak w poprzednich programach skupu obligacji operacjami dostrajającymi (rysunek 6.) $)^{5}$. Nie zostały one jednak uruchomione, lecz komunikaty o możliwości ich wprowadzenia pomogły złagodzić napięcia na rynkach finansowych w drugiej połowie 2012 roku. Przyczynily się one do ogólnej poprawy warunków finansowania, czego dowodem był spadek rentowności obligacji skarbowych w powyższych krajach oraz emisje nowych obligacji przez państwo, banki i przedsiębiorstwa, które dotychczas nie miały dostępu do rynków finansowych.

Mimo to sytuacja jest niepewna, dopóki całkowicie nie zlikwiduje się fundamentalnych przyczyn obecnego kryzysu. Moga tego dokonać jedynie rządy, które powinny ustabilizować dług publiczny, wzmocnić odporność banków i zwiększyć konkurencyjność swoich gospodarek [Raport Roczny..., 2012, s. 16].

W pierwszej połowie 2012 roku było wysokie wykorzystanie depozytów na koniec dnia w banku centralnym. Na skutek redukcji depozytowej stopy procentowej do zera, w lipcu 2012 roku średnie wykorzystanie tego instrumentu zmniejszyło się o ponad połowę, ale banki pozostawiały adekwatnie większe kwoty na rachunkach bieżących (rysunek 6.). Bankom było bowiem obojętne, czy korzystaja z depozytu overnight, czy też pozostawią nadwyżkę płynności na rachunkach bieżących, która także jest nieoprocentowana.

Instytucje kredytowe Eurosystemu były zobowiązane do utrzymywania rezerwy obowiązkowej na rachunkach w banku centralnym w wysokości $2 \%$ podstawy jej naliczania. W celu wsparcia dynamiki kredytów banków dnia 8 grudnia 2011 roku EBC zdecydował o zmniejszeniu stopy rezerwy obowiązkowej do $1 \%$, począwszy od okresu jej utrzymywania (rozpoczynającego się 18 stycznia 2012 roku) zmniejszyło to o połowę kwoty rezerwy obowiązkowej, zwiększając tym samym płynność (o 106 mld euro) do wykorzystania na kredyty (rysunek 6.).

W 2012 roku Europejski Bank Centralny podjął działania zwiększające dostępność zabezpieczeń dla kontrahentów. Banki centralne państw strefy euro uzyskały możliwość, po uzyskaniu zgody EBC, przyjmowania dodatkowych należności kredytowych spełniających kryteria kwalifikowalności jako zabezpieczenia w operacjach kredytowych Eurosystemu. Odpowiedzialność za przyjmowanie takich należności ponoszą krajowe banki centralne zatwierdzające ich wykorzystanie. Dzięki temu Eurosystem był w stanie zapewnić bankom wymagana płynność umożliwiająca reakcję na gorsze funkcjonowanie rynku pieniężnego.

Celem Europejskiego Banku Centralnego w warunkach normalnych i w czasie kryzysu finansowego jest utrzymanie inflacji na poziomie poniżej, ale blisko $2 \%$. Uwzględniając dużą ilość wyemitowanego taniego pieniądza w badanym okresie, nasuwa się py-

5 W 2012 roku był kontynuowany program SMP, zakończony we wrześniu wraz z ogłoszeniem szczegółów programu OMT. Do końca października realizowano również program zakupu zabezpieczonych obligacji CBPP2. 
tanie: czy, oprócz zapewnienia płynności finansowej Eurosystemowi, EBC zrealizował również cel inflacyjny. Otóż w 2008 roku, w czasie rozpoczęcia kryzysu finansowego, inflacja była rekordowo wysoka - 3,3\%. W 2009 roku stopa inflacji wyniosła 0,3\% i była najniższa od wprowadzenia euro w 1999 roku. W 2010 roku osiagnęła 1,6\%, w 2011 roku - 2,7\%, a w 2012 roku utrzymywała się także na podwyższonym poziomie, lecz nieznacznie spadła do $2,5 \%$.

\section{Podsumowanie}

Badany kryzys finansowy rozpoczął się we wrześniu 2008 roku w USA. Jego przesłanką była polityka taniego pieniądza FED, która doprowadziła do zalania światowego rynku tanim dolarem. Skutkiem nadpłynności systemu bankowego USA były tanie kredyty hipoteczne podwyższonego ryzyka (subprime), a te były łączone w pakiety przez firmy inwestycyjne, przekształcone w obligacje oferowane instytucjom finansowym. W tworzeniu bańki spekulacyjnej, polegającej na wzroście popytu, cen nieruchomości i papierów wartościowych z sekurytyzacji kredytów hipotecznych, uczestniczyły również banki strefy euro.

Zaprzestanie tej polityki przez FED, w wyniku podwyższania stóp procentowych w celu zahamowania hossy na rynku nieruchomości, wywołało spadek cen nieruchomości, papierów wartościowych i obniżenia wartości zabezpieczeń kredytowych. Negatywnie odbiło się to w bilansach emitentów i inwestorów oraz doprowadziło do upadłości jednego z czołowych kreatorów tego przedsięwzięcia, przez co banki utraciły zainwestowane aktywa i płynność finansową.

W odpowiedzi na kryzys finansowy EBC zainicjowal niestandardowe działania zwiększające płynność finansową banków. Miały one na celu zapewnienie ciąłości pośrednictwa finansowego w strefie euro, a także pobudzenie akcji kredytowej w stosunku do przedsiębiorstw i gospodarstw domowych. Do działań tych można zaliczyć:

- nieograniczone zasilanie w płynność dla różnych okresów zapadalności przy adekwatnej obniżce stóp procentowych zwiększającej popyt na pieniądz;

- $\quad$ zwiększenie płynności w dolarach USA i frankach szwajcarskich poprzez operacje repo i swapy walutowe $z$ bankami centralnymi tych państw;

- $\quad$ rozszerzenie listy aktywów akceptowanych jako zabezpieczenie operacji zasilających Eurosystem dla banków;

- $\quad$ wprowadzenie programów zakupu przez Eurosystem nadmiaru obligacji skarbowych od banków w celu przywrócenia równowagi rynku tych papierów i transferu płynności z banków posiadających nadmiar płynności do banków z nadmiarem obligacji.

Różne zakłócenia rynków finansowych Eurosystemu były dynamiczne i często nieprzewidywalne, toteż na uwagę zasługuje szybkość i zmienność działań EBC. Niewatpliwie, te kosztowne i ryzykowne działania EBC zabezpieczyły rynki przed ryzykiem płynności, lecz nie uchroniły gospodarki przed kryzysem gospodarczym. 


\section{Literatura}

Al-Kaber M. 2009 Krysyys mieszkeanionych kredytón hipotecznych w US A - praycsyny i skutki, „Optimum. Studia Ekonomiczne”, nr 2.

Bankowość a krysys na rynkach finansowych, 2010, A. Janc (red.), Wydawnictwo Uniwersytetu Ekonomicznego, Poznań.

Bednarczyk J. L., Przybylska-Kapuścińska W. 2011 Od krysysu do ożymienia. Dylematy wspótczesnej polityki finansowej, $\mathrm{CeDeWu}$, Warszawa.

„Biuletyn Miesięczny”, 2011, nr 9, EBC.

Gospodarka i polityka makroekonomiczna strefy euro w latach 2008-2010. Skutki krysysu i stabość zarzadzania, B. Mucha-Leszko (red.), Wydawnictwo Uniwersytetu Marii Curie-Skłodowskiej, Lublin.

Huterski R. 2012 Polityka pienieżna Europejskiego Banku Centralnego a globalny krysys finansony, Studia i Prace Kolegium Zarządzania i Finansów, Zeszyt Naukowy 120, Warszawa.

Mereks M. 2012 Pakiet stabilizacji finansowej strefy euro - analiza instytucjonalno-funkcjonalna, Studia i Prace Kolegium Zarządzania i Finansów, Zeszyt Naukowy 120, Warszawa.

Niczyporuk P., Talecka A. 2010 Bankowosí Unii Europejskiej, Temida 2, Białystok.

Paździor A. 2013 Krysys finansony i jego skutki dla gospodarki Polski i swiata, Difin, Warszawa.

Płókarz R. 2013 Globalne rynki finansowe. Praktyka funkcjonalności, Wydawnictwo Naukowe PWN, Warszawa.

Polityka ekonomicrna i rynki finansowe a funkcjonowanie gospodarki, 2013, M. Pronobis (red.), Prace Naukowe WSB, Gdańsk.

Raport Roczny, 2008, EBC.

Raport Roczny, 2009, EBC.

Raport Rocæny, 2010, EBC.

Raport Roczny, 2011, EBC.

Raport Roczny, 2012, EBC.

Schaal P. 1996 Pieniadz i polityka pienieżna, Państwowe Wydawnictwo Ekonomiczne, Warszawa.

Wytyczne EBC ₹ dnia 20 września 2011 roku w sprawie instrumentów $i$ procedur polityki pienię̇nej Eurosystemu, Dziennik Urzędowy Unii Europejskiej, dokument elektroniczny, tryb dostępu: [http://www.ebc.int/p..., data wejścia: 12.05.2014].

Zarzecki J. 2004 Plynność rynków finansonych, Wydawnictwo Wyższej Szkoły Ekonomicznej, Białystok.

Zarzecki J. 2005 Ptynność finansowa bankón w Polsce, „Optimum, Studia Ekonomiczne”, nr 4. 